Original Research Paper

\title{
Comparison of Lung Capacity in Communities in Low Land and High Land
}

\author{
Norma Juniati $^{1 *}$, Syamsul Bahri ${ }^{1,2}$, Yenni Desimarlina ${ }^{1}$, Annisa Zikri \\ Robbia $^{1}$, Ainun Jariah ${ }^{1}$, Husnul Fuadi ${ }^{1}$ \\ ${ }^{1}$ Departement of Sciences Education Postgraduate Mataram University, Indonesia \\ ${ }^{2}$ Departement of Biological Sciences Education, Faculty of Teacher Training and Education, Mataram \\ University, Indonesia;
}

\author{
Article History \\ Received : January $07^{\text {th }}, 2021$ \\ Revised : January $10^{\text {th }}, 2021$ \\ Accepted : January $18^{\text {th }}, 2021$ \\ Published : January $22^{\text {th }}, 2021$ \\ *Corresponding Author: \\ Norma Juniati, \\ Departement of Sciences \\ Education Postgraduate \\ Mataram University, Indonesia \\ Email: \\ normajuniati16@gmail.com
}

\begin{abstract}
The environment in which they live has a major influence on the development of a person's physical characteristics and abilities. One of the physical capacities that is strongly influenced by the anthropometric measurements of the body and the body's adaptability to the environment is the vital capacity of the lungs. The vital capacity is the maximum volume of air that can enter and leave the lungs during one breathing cycle after maximum inspiration and maximum expiration. This study aims to determine the difference in the vital capacity of the lungs in the people in the lowlands of Mataram city and the highlands of Sembalun village. Sampling was done using purposive sampling technique with a sample of 20 people in each research area with an age range of 21-25 years. The data were collected using a simple spirometer made by the researcher. The control variables in this study included gender, age, height, body weight and sample hemoglobin levels. The results showed the average value of vital lung capacity in the lowlands was $2837.5 \mathrm{ml}$, while the vital capacity of the lungs in the highlands was $2767.5 \mathrm{ml}$. The results of hypothesis testing were carried out using the Independent Sample t-test using SPSS 16 and the results of the significance value (2-tailed) $0.740>0.05$ so that Ho was accepted, which means that there is no difference in the vital capacity of the lungs in the highlands and lowlands.
\end{abstract}

Keywords: Highlands; Lowlands; Lung Capacity.

\section{Pendahuluan}

Struktur tubuh manusia di seluruh dunia berbeda satu dengan yang lain. Faktor-faktor seperti genetik, ras, jenis kelamin, aktivitas fisik, dan nutrisi merupakan beberapa hal yang dapat mempengaruhi kapasitas paru-paru seseorang. Kondisi geografis tempat tinggal manusia juga dapat mempengaruhi struktur tubuh manusia. Kondisi geografis bumi yang berbeda-beda di setiap wilayahnya akan memberikan rangsangan yang berbeda, sebagai contoh, daerah pantai dan daerah pegunungan akan memberi rangsangan berbeda pada tubuh. Sebagai respons, tubuh akan melakukan adaptasi sehingga berpengarah terhadap keadaan fisiologis.

Lingkungan tempat tinggal memiliki pengaruh besar terhadap perkembangan karakteristik dan kemampuan fisik individu. Pola adaptasi terhadap lingkungan yang terjadi selama bertahun-tahun dalam beberapa periode keturunan akan dapat mengakibatkan perubahan pola adaptasi genetis. Hal ini yang memungkinkan terjadinya perbedaan penampilan fisik yang dimiliki oleh individu yang berasal dari suku yang sama namun telah menetap terpisah selama masa yang panjang di lingkungan dengan karakteristik yang berbeda. Ukuran populasi sosial juga memberi pengaruh terhadap penampilan fisik/performa seseorang dalam penampilan olahraga (Pyne et al., 2009).

Dalam pertumbuhan dan perkembangan kemampuan fisik, faktor lingkungan menjadi sangat penting. Cuaca, musim, dan ketinggian tempat tinggal merupakan beberapa karakteristik lingkungan fisik yang dapat mempengaruhi pola pertumbuhan fisik (Haywood \& Kathleen, 1986). Seorang anak yang lahir dengan fungsi fisiologis tertentu akan mengalami adaptasi dengan kondisi lingkungannya sepanjang proses pertumbuhan 
dan perkembangannya. Ketinggian tempat tinggal sebagai faktor geografis yang berhubungan dengan sifat iklim berpengaruh terhadap bentuk tubuh. Ada kecenderungan orang-orang yang tinggal di dataran tinggi memiliki lingkaran dada dan paru-paru yang lebih besar dari pada orang-orang yang tinggal di dataran rendah (Sugiyanto, 1998). Ketinggian tempat memiliki hubungan yang erat dengan tekanan parsial oksigen $\left(\mathrm{pO}_{2}\right)$ di udara.

Pada daerah dataran tinggi tekanan parsial $\mathrm{O}_{2}$ di udara lebih rendah dibandingkan di dataran rendah, hal ini berpengaruh terhadap kemampuan difusi oksigen dari udara ke alveolus paru. Dengan $\mathrm{pO}_{2}$ di udara lebih rendah, difusi oksigen ke alveolus menjadi lebih sulit. Individu yang lahir dan tinggal di dataran tinggi melakukan adaptasi dengan memperbesar ukuran lingkar dada dan paru-paru. Selain itu, adaptasi yang terjadi terhadap ketinggian tempat (aklimasi) diantaranya peningkatan jumlah sel darah merah dan konsentrasi hemoglobin, eliminasi ion bikarbonat dari urin dan perubahan jaringan tubuh (Foss, Merle, \& Keteyian, 1998). Perubahan jaringan tubuh kemungkinan besar berpengaruh terhadap ukuran antropometrik dari individu. Salah satu kapasitas fisik yang sangat dipengaruhi oleh ukuran antropometri tubuh dan kemampuan adaptasi tubuh terhadap lingkungan adalah kapasitas vital paru. Kapasitas vital merupakan volume udara maksimal yang dapat masuk dan keluar paru-paru selama satu siklus pernapasan setelah inspirasi maksimal dan ekspirasi maksimal. Nilai normal kapasitas vital tergantung pada usia, jenis kelamin, bentuk tubuh, dan berat badan (Smeltzer \& Bare, 2002). Sedangkan menurut Guyton \& Hall (2008), faktor utama yang mempengaruhi kapasitas vital adalah bentuk anatomi tubuh, posisi selama pengukuran kapasitas vital, kekuatan otot pernapasan serta pengembangan paru dan rangka dada (Compliance paru). Kapasitas vital paru memiliki korelasi positif dengan kemampuan fisik seorang atlet. Perbedaan tekanan parsial oksigen antara dataran rendah dan dataran tinggi memiliki pengaruh langsung terhadap adaptasi sistem kardiorespirasi dalam upaya memenuhi kebutuhan oksigen jaringan tubuh. Tekanan parsial oksigen yang rendah memaksa sistem respirasi untuk bekerja lebih keras dalam upaya memenuhi kebutuhan oksigen dalam jaringan. Tekanan oksigen yang rendah mengharuskan sistem respirasi menghirup udara lebih banyak untuk memenuhi kebutuhan oksigen jaringan. Kegiatan inspirasi dan ekspirasi atau menghirup dan menghembuskan udara dalam bernapas hanya menggunakan sekitar $500 \mathrm{cc}$ volume udara pernapasan (kapasitas tidal $= \pm 500 \mathrm{cc}$ ). Volume peningkatan tidal dihasilkan dari volume cadangan inspirasi dan volume ekspirasi yaitu 50-55\% (Berger \& Bradac, 1982).

Secara perhitungan matematis Kapasitas Total Paru-paru (KTP) dapat ditentukan dengan cara mengukur hiperventilasi maksimal dalam satu menit, atau dengan kata lain Kapasitas Vital (KV) ditambah Volume Residual (VR). Jadi nilai Kapasitas Total Paru-paru (KTP) $=\mathrm{KV}+\mathrm{VR}$ (Hernawati, 2008). Kapasitas vital paru adalah kemampuan paru untuk menghisap dan menghembuskan udara secara maksimal (Husein, 2000). Sedangkan menurut Muchtamadji (2000) menyatakan bahwa vital capacity adalah jumlah udara yang dapat dikeluarkan sebanyak-banyaknya setelah melakukan inspirasi sedalam-dalamnya.

Pearce (1993) dalam bukunya menyatakan bahwa volume udara yang dapat dicapai masuk dan keluar paru-paru pada penarikan napas dan pengeluaran napas paling kuat, disebut kapasitas vital paru. Kapasitas vital sama dengan volume cadangan inspirasi ditambah volume tidal dan volume cadangan eskpirasi. Kapasitas vital paru (vital capasity) sangat erat hubungannya dengan pernapasan atau respirasi. Kapasitas vital paru adalah volume udara yang dapat dikeluarkan dari penarikan napas yang dalam. Jumlah maksimal udara yang dapat dihirup dan dikeluarkan oleh paru disebut kapasitas. Hairy (1989), berpendapat kapasital vital adalah jumlah udara maksimal pada ekspirasi yang kuat setelah inspirasi maksimal.

Sewaktu menghirup udara (inspirasi) dinding dada secara aktif tertarik keluar oleh pengerutan dinding dada, dan sekat rongga dada (diafragma) tertarik ke bawah. Berkurangnya tekanan di dalam paru-paru menyebabkan udara mengalir ke paru-paru. Hembusan napas keluar (ekspirasi) disebabkan mengkerutnya paru-paru dan diikuti rongga dada yang menyusut (Tzani et al., 2008).

Peralatan yang dapat digunakan untuk mengukur volume udara yang masuk dan keluar dari paru-paru adalah spirometer. Dari perbedaaan tekanan udara yang diberikan 
seseorang ketika bernafas menyebabkan tabung yang berisi udara akan bergerak naik turun, sementara itu drum pencatat bergerak memutar (sesuai jarum jam) sehingga alat akan mencatat grafik pernapasan (sinyal respirasi) sesuai dengan gerak tabung yang berisi udara. (Martiem, 2005).

Untuk mengetahui bagaimana kapasitas paru-paru yang ada di dataran rendah ataupun dataran tinggi maka diperlukan rancangan penelitian sehingga nanti bisa dijadikan sebagai acuan dalam melaksanakan suatu percobaan sains di sekolah khususya biologi. Oleh karena itu penelitian mengenai "Perbandingan Kapasitas Paru-Paru pada Masyarakat yang Hidup di Dataran Rendah dan Dataran Tinggi Sebagai Kajian Bahan Praktikum pada Mata Kuliah Praktikum IPA" perlu dilakukan.

\section{Bahan dan Metode}

\section{Waktu dan Tempat}

Penelitian perbandingan kapasitas paruparu masyarakat di dataran rendah dan dataran tinggi dilaksanakan pada bulan Oktober 2020 di 2 tempat yakni di dataran rendah Kr. Baru, kota Mataram (0 - $50 \mathrm{mdpl})$ dengan 20 sampel warga dan di dataran tinggi desa Sembalun Bumbung, Lombok Timur (800 - 1200 mdpl) dengan 20 sampel warga sehingga total jumlah responden yaitu 40 warga.

\section{Metode Pengambilan Data}

Penelitian ini termasuk dalam penelitian comparative study yaitu membandingkan dua atau lebih suatu kondisi, kejadian, kegiatan, atau program dan lainnya (Sukmadinata, 2012). Teknik pengambilan sample purposive sampling yaitu teknik pengambilan sampel tidak berdasarkan random, daerah atau strata, melainkan berdasarkan atas apa adanya pertimbangan yang berfokus pada tujuan tertentu (Arikunto, 2002).

Pengumpulan data dilakukan dengan menggunakan spirometer sederhana yang dibuat oleh peneliti untuk mengetahaui kapasitas paruparu masyarakat di dataran rendah dan dataran tinggi. Langkah kerja penggunaan spirometer sederhana dengan melakukan satu kali inspirasi pada pernapasan dada dan menahan napas. Setelah itu mengarahkan bagian ujung selang ke mulut setelah melakukan inpirasi. Selanjutnya melakukan tahap ekspirasi dengan menghembuskan udara yang tersimpan dengan satu kali hembusan napas. Setelah itu peneliti melakukan pengukuran pada sisa air jerigen. Kapasitas total paru-paru dikurangi dengan sisa air didalam jerigen dan hasil perhitungan tersebut merupakan kapasitas vital paru-paru seseorang. Setiap orang melakukan pengulangan sebanyak tiga kali agar mendapatkan hasil yang lebih akurat. Perbedaan dengan spirometer pada umumnya yaitu pada hasil perhitungan spirometer pada umumnya lebih dapat menilai status kapasitas paru untuk menentukan apakah seseorang mempunyai kapasitas paru normal, hiperinflasi, obstruksi, restriksi atau bentuk campuran, dan dapat mengevaluasi penyakit yaitu menilai laju perkembangan penyakit terdapat perbaikan atau perubahan nilai kapasitas paru sedangkan pada spirometer yang dibuat oleh peneliti hanya untuk mengetahui berapa jumlah nilai kapasitas vital paru-paru seseorang. Hasil uji hipotesis dilakukan dengan menggunakan uji Independent Sample t-test menggunakan SPSS 16 untuk mengetahui apakah ada perbedaan kapasitas paru-paru masyarakat yang hidup di dataran rendah dan dataran tinggi.

\section{Hasil dan Pembahasan}

\section{Kapasitas paru - paru}

Paru - paru merupakan organ pada sistem pernapasan yang berperan penting sebagai tempat pertukaran oksigen dan karbondioksida dalam tubuh. Kapasitas paru-paru merupakan gabungan dari beberapa volume paru-paru dan dibagi menjadi empat bagian, yaitu kapasitas inspirasi, kapasitas residu fungsional, kapasitas vital, dan kapasitas paru-paru total. Kapasitas paru pada setiap individu berbeda-beda tergantung dari usia, tinggi badan, berat badan, kadar $\mathrm{Hb}$ dan juga tempat tinggal.

Kapasitas vital paru-paru merupakan jumlah oksigen yang dapat dimasukkan kedalam tubuh atau paru sesorang secara maksimal. Jumlah oksigen yang dapat dimasukkan kedalam paru ditentukan oleh kemampuan kembang kempisnya sistem pernapasan. Semakin baik kerja sistem pernapasan berarti volume oksigen yang diperoleh semakin banyak. Dengan kata lain, kapasias vital paru-paru merupakan status kondisi fisiologis yang berkaitan dengan kemampuan pengolahan udara pernapasan. 
Pengukuran kapasitas paru-paru menggunakan alat berupa spirometer sederhana dengan menggunakan peralatan sederhana berupa jerigen yang diisi air dan dihubungkan selang sebagai media untuk membantu proses pengambilan data, kemudian setelah itu jerigen dibalikkan ke wadah ember yang berisi air. Sebelum pengambilan data sampel responden peneliti lebih dahulu membuat daftar tabel faktor-faktor pendukung diantaranya seperti nama, umur, jenis kelamin, tinggi badan, berat badan, dan kadar Hb.
Penelitian perbandingan kapasitas paruparu dilaksanakan di dua lokasi yakni di Karang Baru, Mataram sebagai lokasi dataran rendah dan di desa Sembalun Bumbung, Lombok Timur sebagai dataran tinggi. Letak Kota Mataram $0-$ 50 mdpl dengan suhu udara $20 \quad-33{ }^{\circ} \mathrm{C}$. Sedangkan Letak desa Sembalun 800-1200 mdpl dengan suhu udara $14-23{ }^{\circ} \mathrm{C}$, kelembapan $86 \%$. Jumlah sampel sebanyak 20 orang warga masing-masing lokasi penelitian dengan rentan umur dari $21-25$ tahun.

Tabel 1. Kapasitas paru-paru di Dataran Rendah

\begin{tabular}{|c|c|c|c|c|c|c|c|c|c|c|}
\hline \multirow{3}{*}{ No. } & \multirow{3}{*}{ Nama } & \multicolumn{9}{|c|}{ Variabel Penelitian } \\
\hline & & \multirow[b]{2}{*}{ Umur } & \multirow{2}{*}{$\begin{array}{c}\text { Jenis } \\
\text { Kelamin }\end{array}$} & \multirow{2}{*}{$\begin{array}{c}\text { Tinggi } \\
\text { Badan } \\
(\mathrm{cm})\end{array}$} & \multirow{2}{*}{$\begin{array}{c}\text { Berat } \\
\text { Badan } \\
(\mathrm{kg})\end{array}$} & \multirow[b]{2}{*}{$\begin{array}{c}\text { Kadar } \\
\text { HB }\end{array}$} & \multicolumn{4}{|c|}{ Kapasitas Paru-Paru } \\
\hline & & & & & & & U1 & $\mathrm{U} 2$ & U3 & Rerata \\
\hline 1 & Citra & 21 & $\mathrm{P}$ & 172 & 92 & 12,8 & 3650 & 3750 & 3700 & 3700 \\
\hline 2 & Faizah & 24 & $\mathrm{P}$ & 156 & 65 & 14,1 & 2550 & 2700 & 2850 & 2700 \\
\hline 3 & Rian Hartori & 25 & $\mathrm{~L}$ & 153 & 41 & 14,8 & 3100 & 2850 & 2900 & 2950 \\
\hline 4 & Iqbal Fansuri & 24 & $\mathrm{~L}$ & 162 & 71 & 15,3 & 3000 & 2850 & 3000 & 2950 \\
\hline 5 & Lalu Reza & 23 & $\mathrm{~L}$ & 174 & 64 & 16,8 & 3100 & 3350 & 3150 & 3200 \\
\hline 6 & Ramdani & 24 & $\mathrm{~L}$ & 171 & 63 & 16,8 & 3550 & 3400 & 3400 & 3450 \\
\hline 7 & Dilla Anbar & 25 & $\mathrm{P}$ & 153 & 73 & 15,2 & 1650 & 1750 & 1700 & 1700 \\
\hline 8 & Ria Nurpia & 22 & $\mathrm{P}$ & 152 & 45 & 13,4 & 2500 & 2450 & 2400 & 2450 \\
\hline 9 & Khairil & 23 & $\mathrm{~L}$ & 166 & 69 & 16,2 & 2800 & 2600 & 2700 & 2700 \\
\hline 10 & Wisnu Arga & 22 & $\mathrm{~L}$ & 178 & 60 & 15,3 & 3250 & 3300 & 3050 & 3200 \\
\hline 11 & Hari Kurnia & 24 & $\mathrm{~L}$ & 170 & 66 & 19,3 & 4000 & 3850 & 4000 & 3950 \\
\hline 12 & Rama & 23 & $\mathrm{~L}$ & 164 & 70 & 14,5 & 3200 & 3250 & 3150 & 3200 \\
\hline 13 & Hasnawati & 23 & $\mathrm{P}$ & 153 & 50 & 12,8 & 2300 & 2100 & 2200 & 2200 \\
\hline 14 & Nurwahidah & 23 & $\mathrm{P}$ & 157 & 55 & 11,8 & 1950 & 1900 & 2000 & 1950 \\
\hline 15 & Intan & 24 & $\mathrm{P}$ & 158 & 70 & 15,9 & 2500 & 2450 & 2400 & 2450 \\
\hline 16 & Eka Pujianti & 21 & $\mathrm{P}$ & 148 & 41 & 17,1 & 2300 & 2200 & 2100 & 2200 \\
\hline 17 & Novri Asma & 23 & $\mathrm{P}$ & 157 & 55 & 12,0 & 3050 & 2900 & 2900 & 2950 \\
\hline 18 & Dira Haryani & 21 & $\mathrm{P}$ & 156 & 45 & 14,1 & 1850 & 2000 & 2000 & 1950 \\
\hline 19 & Malkan & 23 & $\mathrm{~L}$ & 162 & 49 & 19,3 & 3500 & 3450 & 3400 & 3450 \\
\hline 20 & Bagus Rangga & 21 & $\mathrm{~L}$ & 161 & 50 & 17,2 & 3400 & 3400 & 3550 & 3450 \\
\hline \multicolumn{4}{|c|}{ Total } & 3223 & 1194 & 304,7 & 57200 & 56500 & 56550 & 56750 \\
\hline \multicolumn{4}{|c|}{ Rata-Rata } & 161,15 & 59,7 & 15,235 & 2860 & 2825 & 2827,5 & 2837,5 \\
\hline
\end{tabular}

Pada tabel 2 didapatkan hasil pengamatan kapasitas paru-paru masyarakat di dataran tinggi. Tabel hasil pengamatan dilakukan 3 kali pengulangan agar hasil lebih akurat setelah itu dirata-ratakan. Nilai rerata kapasitas paru-paru yang berada di dataran rendah sebesar 2767,5 ml.

Tabel 2. Kapasitas paru-paru di Dataran Tinggi

\begin{tabular}{|c|c|c|c|c|c|c|c|c|c|c|}
\hline \multirow{3}{*}{ No. } & \multirow{3}{*}{ Nama } & \multicolumn{9}{|c|}{ Variabel Penelitian } \\
\hline & & \multirow[b]{2}{*}{ Umur } & \multirow[b]{2}{*}{$\begin{array}{c}\text { Jenis } \\
\text { Kelamin }\end{array}$} & \multirow{2}{*}{$\begin{array}{l}\text { Tinggi } \\
\text { Badan } \\
(\mathrm{cm})\end{array}$} & \multirow{2}{*}{$\begin{array}{c}\text { Berat } \\
\text { Badan } \\
(\mathrm{kg})\end{array}$} & \multirow{2}{*}{$\begin{array}{c}\text { Kadar } \\
\text { HB }\end{array}$} & \multicolumn{4}{|c|}{ Kapasitas Paru-Paru } \\
\hline & & & & & & & U1 & $\mathrm{U} 2$ & U3 & Rerata \\
\hline 1 & Itnu Irawan & 21 & $\mathrm{~L}$ & 164 & 54 & 18,3 & 3450 & 3500 & 3400 & 3450 \\
\hline 2 & Nurhidayati & 22 & $\mathrm{P}$ & 157 & 64 & 11,7 & 2550 & 2400 & 2400 & 2450 \\
\hline 3 & Saini & 23 & $\mathrm{~L}$ & 156 & 43 & 16,1 & 3600 & 3450 & 3300 & 3450 \\
\hline 4 & Titiani & 21 & $\mathrm{P}$ & 144 & 40 & 13,6 & 2000 & 1900 & 1950 & 1950 \\
\hline 5 & Malhatun & 25 & $\mathrm{P}$ & 156 & 51 & 14,9 & 1950 & 2050 & 1850 & 1950 \\
\hline
\end{tabular}


Juniati, N. et al. (2021). Jurnal Biologi Tropis, 21 (1): 95-102 DOI: http://dx.doi.org/10.29303/jbt.v21i1.2359

\begin{tabular}{|l|l|l|l|l|l|l|l|l|l|l|}
\hline 6 & Zuharni & 25 & $\mathrm{P}$ & 143 & 45 & 10,4 & 1800 & 1650 & 1650 & 1700 \\
\hline 7 & Rohani & 24 & $\mathrm{P}$ & 146 & 42 & 10,5 & 2600 & 2500 & 2250 & 2450 \\
\hline 8 & Gita Irmayanti & 22 & $\mathrm{P}$ & 148 & 42 & 13,9 & 2300 & 2250 & 2200 & 2250 \\
\hline 9 & Caca & 24 & $\mathrm{P}$ & 152 & 44 & 11,7 & 2550 & 2300 & 2500 & 2450 \\
\hline 10 & Widi & 21 & $\mathrm{P}$ & 152 & 42 & 11,5 & 2300 & 2150 & 2150 & 2200 \\
\hline 11 & Firza & 21 & $\mathrm{P}$ & 155 & 61 & 14,2 & 2850 & 2700 & 2550 & 2700 \\
\hline 12 & Siti Naziatul & 24 & $\mathrm{P}$ & 144 & 38 & 7,2 & 1950 & 1850 & 2050 & 1950 \\
\hline 13 & Martin & 25 & $\mathrm{~L}$ & 166 & 61 & 13,3 & 3850 & 3600 & 3650 & 3700 \\
\hline 14 & Rosiana & 24 & $\mathrm{P}$ & 149 & 78 & 13,4 & 2950 & 2900 & 3000 & 2950 \\
\hline 15 & Siskayanti & 23 & $\mathrm{P}$ & 155 & 69 & 11,9 & 2950 & 2550 & 2650 & 2700 \\
\hline 16 & Udin & 25 & $\mathrm{~L}$ & 167 & 63 & 11,1 & 2700 & 2600 & 2800 & 2700 \\
\hline 17 & Sandriono & 25 & $\mathrm{~L}$ & 162 & 54 & 15,3 & 3550 & 3500 & 3300 & 3450 \\
\hline 18 & Marsoni & 25 & $\mathrm{~L}$ & 158 & 50 & 15,9 & 3500 & 3400 & 3450 & 3450 \\
\hline 19 & Rizki & 21 & $\mathrm{~L}$ & 166 & 64 & 16,9 & 4350 & 4150 & 4150 & 4200 \\
\hline 20 & Zulkifli & 25 & $\mathrm{~L}$ & 160 & 56 & 12,9 & 3150 & 3300 & 3300 & 3250 \\
\hline Total & & 3100 & 1061 & 264,7 & 56900 & 54700 & 54550 & 55350 \\
\hline Rata-Rata & & 155 & 53,05 & 13,235 & 2845 & 2735 & 2727,5 & 2767,5 \\
\hline
\end{tabular}

Nilai kapasitas vital paru - paru

Pada tabel 3 didapatkan hasil distribusi frekuensi tingkat kapasitas vital paru-paru pada masyarakat dataran rendah memiliki rerata nilai kapasitas vital yaitu 2837,5 ml dengan kategori baik dan dataran tinggi memiliki rerata nilai kapasitas vital yaitu 2767,5 ml dengan kategori baik.

Pada hasil penelitian didapatkan bahwa tidak terdapat perbedaan kapasitas vital paruparu masyarakat yang berada di dataran rendah dan dataran tinggi. Nilai kapasitas vital paru-paru pada dataran rendah yaitu $2837,5 \mathrm{ml}$ sedangkan kapasitas vital paru-paru pada dataran tinggi yaitu $2767,5 \mathrm{ml}$. Nilai dari rerata kapasitas vital paru-paru di dataran rendah dan dataran tinggi tidak jauh berbeda. Hal ini bisa dikarenakan rentang ketinggian antara dataran rendah dan dataran tinggi tidak terlalu jauh. Rentang untuk dataran rendah di Kota mataram berkisar 0-50 mdpl dan untuk dataran tinggi di Sembalun berkisar 800-1200 mdpl. Perbedaan kedua tempat ini berkisar 800-1000 mdpl dengan tekanan barometrik dari $760 \mathrm{mmHg}$ menjadi 523 $\mathrm{mmHg}$, penurunan $\mathrm{PO} 2$ dalam udara dari 150 $\mathrm{mmHg}$ menjadi $110 \mathrm{mmHg}$, dan penurunan alveoli dari $104 \mathrm{mmHg}$ menjadi $67 \mathrm{mmHg}$ akan terjadi pada kenaikan $10.000 \mathrm{ft}$ (3048 mdpl). Penurunan nilai yang terjadi pada tekanan barometrik, PO2 udara, dan $\mathrm{PO} 2$ alveoli ialah $<10 \%$. Nilai persentase yang rendah ini diperkirakan menjadi salah satu penyebab faktor yang menyebabkan rerata nilai kapasitas vital paru-paru responden di kedua tempat tidak jauh berbeda sehingga hasil uji tidak signifikan.
Penyebab atau faktor lain yang mengakibatkan perbedaan kapasitas vital paruparu masyarakat yang berada di dataran rendah dan dataran tinggi tidak jauh berbeda, bahkan bisa dikatakan nilai kapasitas vital paru-paru di dataran rendah lebih tinggi bisa diakibatkan karena kondisi lingkungan yang ada di dataran rendah yaitu Kota Mataram bisa dikatakan cukup sehat, dapat dilihat bagaimana aktivitas dalam kehidupan mereka sehari-hari seperti rutin berolahraga, makan-makanan yang sehat, dan beristirahat yang cukup. Berbeda halnya pada mayarakat yang berada di dataran tinggi yaitu Sembalun Bumbung, Lombok Timur memiliki aktivitas lebih banyak sebagai petani, jadi olahraga atau mengeluarkan hasil ekskresi yaitu keringat bisa dikatakan dari aktivitas yang mereka lakukan sehari-hari. Masyarakat yang berada di Sembalun Bumbung lebih sering merokok dan minum kopi karena memang cuaca yang ada di dataran tinggi cukup dingin. Aktivitas masyarakat yang hidup di dataran tinggi yaitu tidur terlalu larut juga dapat menjadi salah satu faktor tidak adanya perbedaan yang signifikan dengan dataran rendah.

Repondensi baik umur, $\mathrm{Hb}$, jenis kelamin, tinggi badan, berat badan pada dataran rendah maupun dataran tinggi tidak terlihat adanya perbedaan. Jadi banyak faktor yang menyebabkan tidak terdapat perbedaan yang signifikan di dataran rendah maupun dataran tinggi mulai dari perbedaan ketinggian, aktivitas mayarakat di kedua wilayah, posisi tubuh yang kurang tepat pada saat pengambilan data, sampel yang dilakukan pada saat penelitian hanya sedikit yaitu 20 warga dari masing-masing wilayah 
penelitian, jenis kelamin, tinggi badan, berat badan, umur. Usia berhubungan dengan proses penuaan atau bertumbuhnya umur. Semakin tua usia seseorang maka semakin besar kemungkinan terjadi penurunan fungsi paru
(Suyono, 1995). Kadar hemoglobin juga dapat mempengaruhi kapasitas vital paru-paru. Kadar hemoglobin darah normal pada pria $14 \mathrm{gram} / \mathrm{dl}$ dan pada wanita 12 gram/dl (Ganong, 1998).

Tabel 3. Hasil Distribusi Frekuensi Tingkat Kapasitas Vital Paru Masyarakat Dataran Tinggi

\begin{tabular}{|c|c|c|c|}
\hline Interval (ml) & Kategori & Responden DT & Responden DR \\
\hline$>3250$ & Baik sekali & 6 & 5 \\
\hline $2439-3249$ & Baik & 8 & 10 \\
\hline $1789-2438$ & Sedang & 5 & 5 \\
\hline $1301-1788$ & Kurang & 1 & - \\
\hline Total & Kurang sekali & 20 & 20 \\
\hline
\end{tabular}

Sumber: (Pitriamaryani, 2019)

\section{Distribusi Responden}

Pada tabel 4 didapatkan distribusi responden pada dataran rendah dan dataran tinggi berdasarkan umur, tinggi badan, berat badan dan kadar hemoglobin. Pada dataran rendah lebih banyak dengan responden umur 23 tahun sedangkan pada dataran tinggi yaitu 25 tahun. Pada kadar Hb di dataran rendah maupun dataran tinggi hampir sama dilihat dari respondensi dataran rendah dan dataran tinggi yaitu berkisar 11-15 gr/dL. Baik dari segi tinggi badan dan berat badan juga relatif sama baik dataran tinggi maupun dataran rendah. Jadi dapat dikatakan, dari hasil penelitian di dataran rendah maupun dataran tinggi, didapatkan responden baik dari segi umur, jenis kelamin, tinggi badan, berat badan, dan kadar $\mathrm{Hb}$ tidak jauh berbeda.
Nilai kapasitas vital paru-paru dipengaruhi oleh beberapa faktor diantaranya umur, jenis kelamin, berat badan, tinggi badan, dan hemoglobin. Pada umur dataran rendah cenderung masyarakat dengan umur 23 tahun sedangkan pada dataran tinggi yaitu 25 tahun. Pada kadar $\mathrm{Hb}$ di dataran rendah maupun dataran tinggi hampir sama dilihat dari respondensi dataran rendah dan dataran tinggi yaitu berkisar 11-15 gr/dL. Baik dari segi tinggi badan dan berat badan juga relatif sama baik dataran rendah maupun dataran tinggi. Jadi dapat dikatakan, dari hasil penelitian di dataran rendah maupun dataran tinggi, didapatkan responden baik dari segi umur, jenis kelamin, tinggi badan, berat badan, dan kadar $\mathrm{Hb}$ tidak jauh berbeda, dapat dilihat dari persentase data pada kedua wilayah tersebut.

Tabel 4. Distribusi Responden Dataran Rendah dan Dataran Tinggi.

\begin{tabular}{|l|c|c|}
\hline \multicolumn{1}{|c|}{ Faktor } & Responden Dataran Rendah & Responden Dataran Tinggi \\
\hline Umur & 23 tahun, 7 orang $(35 \%)$ & 25 tahun, 7 orang $(35 \%)$ \\
\hline Tinggi badan & $151-160 \mathrm{~cm}, 9$ orang $(45 \%)$ & $151-160 \mathrm{~cm}, 8$ orang $(40 \%)$ \\
\hline Berat badan & $41-50 \mathrm{~kg}, 7$ orang $(35 \%)$ & $41-50 \mathrm{~kg}, 7$ orang $(35 \%)$ \\
\hline Hemoglobin & $11-15 \mathrm{gr} / \mathrm{dL}, 13$ orang $(65 \%)$ & $11-15 \mathrm{gr} / \mathrm{dL}, 14$ orang $(70 \%)$ \\
\hline
\end{tabular}

Pada tabel 5 dilakukan uji $\mathrm{t}$ untuk mengetahui apakah ada perbedaan kapasitas paru-paru masyarakat di dataran rendah dan dataran tinggi. Diketahui hasil uji hipotesis thitung sebesar 0,740>0,05 yang berarti Ho diterima. Kesimpulan dari penelitian ini menunjukkan bahwa tidak terdapat perbedaan kapasitas paru-paru masyarakat yang hidup di dataran rendah dan dataran tinggi. 
Juniati, N. et al. (2021). Jurnal Biologi Tropis, 21 (1): 95- 102

DOI: http://dx.doi.org/10.29303/jbt.v21i1.2359

Tabel 5. Uji Independent Sample t-test

\begin{tabular}{|l|l|l|l|l|l|l|}
\hline \multicolumn{2}{|c|}{} & \multicolumn{2}{|c|}{$\begin{array}{l}\text { Levene's } \\
\text { Test for } \\
\text { Equality of } \\
\text { Variances }\end{array}$} & \multicolumn{2}{|c|}{} \\
\cline { 2 - 7 } & F & Sig & t & df & $\begin{array}{l}\text { Sig. (2- } \\
\text { tailed) }\end{array}$ \\
\hline $\begin{array}{l}\text { Paru- } \\
\text { paru }\end{array}$ & $\begin{array}{l}\text { Equal } \\
\text { variances } \\
\text { assumed }\end{array}$ & .229 & .635 & -.334 & 38 & .740 \\
\hline & $\begin{array}{l}\text { Equal } \\
\text { variances } \\
\text { not } \\
\text { assumed }\end{array}$ & & & -.334 & 37.677 & .740 \\
\hline
\end{tabular}

Setelah dilakukan uji Independent Sample t-test diketahui hasil uji hipotesis t-hitung sebesar 0,740>0,05 yang berari Ha ditolak dan Ho diterima sehingga tidak terdapat perbedaan antara kapasitas vital paru-paru di dataran rendah dan dataran tinggi. Hasil penelitian tersebut juga sama dengan hasil penelitian Tambunan (2016) yang menyatakan bahwa kapasitas vital paruparu pada pelajar di dataran tinggi Tomohon dengan pelajar di dataran rendah Manado pada tahun 2016 yang dikemukakan oleh Rainbow D. Tambunan, Venneta R. Danes, Fransiska Lintong menunjukkan bahwa tidak terdapat perbedaan bermakna antara kapasitas vital paru-paru pada pelajar di dataran rendah maupun dataran tinggi karena pada hasil uji $\mathrm{T}$ sendiri menunjukkan tidak ada perbedaan signifikan dari ketinggian yang berbeda tersebut.

\section{Kesimpulan}

Masyarakat di dataran rendah memiliki rerata nilai kapasitas vital paru-paru yaitu 2837,5 $\mathrm{ml}$ dengan kategori baik dan masyarakat di dataran tinggi memiliki rerata nilai kapasitas vital paru-paru yaitu 2767,5 ml dengan kategori baik. Tidak terdapat perbedaan kapasitas paruparu masyarakat yang hidup di dataran rendah dan dataran tinggi. Hal ini disebabkan karena pada hasil uji Independent Sample t-test didapatkan t-hitung sebesar 0,740>0,05 yang berarti Ha ditolak.

\section{Ucapan terima kasih}

Ucapan terima kasih kepada Bapak kepala Desa Kr. Baru kota Mataram dan kepala desa Sembalun Bumbung yang telah memberikan izin mengambil data penelitian.

\section{Referensi}

Arikunto, S. (2002). Prosedur Penelitian. Suatu Pendekatan praktek. Jakarta; Rineka Cipta.

Berger, C. R., \& Bradac, J. J. (1982). Language and social knowledge: Uncertainty in interpersonal relations (Vol. 2). Hodder Education. DOI 10.1353/lan.1984.0044

Foss, Merle L. \& Steven J. Keteyian (1998). Fox's Physiological Basis for Exercise and Sport. Dubuque: The McGraw-Hill Companies, Inc.

Ganong, Wiliam F. (1998). Review of Medical Phisyology. (M. Djauhri Wijaya Kesumeh. Terjemahan). Jakarta: Penerbit Buku Kedokteran EEC. Buku asli diterbitkan tahun 1988.

Guyton, A. C., \& Hall, J. E. (2008). Buku ajarFisiologi kedokteran (Eds. 11)(Irawati, Dian Ramadhani, Fara Indriyani, Frans Dany, Imam Nuryanto, Srie Sisca Prima Rianti, Titiek Resmisari \& Y. Joko Suyono, Penerjemah). Jakarta: EGC.

Hairy, Junusul (1989). Fisiologi Olahraga Jilid I. Jakarta: Depdikbud Derektorat Jendral Perguruan Tinggi.

Haywood, Kathleen M. (1986). Life Span Motor Development. Illinois: Human Kinetic Publisher, Inc.

Hernawati (2008). Sistem Pernapasan Manusia pada Kondisi Latihan dan Perbedaan Ketinggian.

Husein, Umar (2000). Metode Riset Edisi 1. Jakarta: Gramedia.

Mawi, M. (2005). Nilai Rujukan Spirometri untuk Lanjut Usia Sehat. Universa Medicina, 24(3), 126. 
Muchtamaji, M. Ali \& Cecep Habibudin (2000). Ilmu Faal Dasar. Jakarta: Depdikbud.

Pyne, D. B., Mujika, I., \& Reilly, T. (2009). Peaking for optimal performance: Research limitations and future directions. Journal of sports sciences, 27(3), 195-202. https://www.tandfonline.com/doi/abs/10.1 $\underline{080 / 02640410802509136}$

Pearce.E.C. (1993). Anatomi Fisiologi. Jakarta: Karya Cipta.

Pitriamaryani, T., \& Syahrastani, S. (2019). Perbandingan Kapasitas Vital Paru-Paru Siswa Perokok Dan Tidak Perokok di SMP Negeri 23 Padang. Jurnal JPDO, 2(9),10-14.

http://jpdo.ppj.unp.ac.id/index.php/jpdo/a rticle/view/591

Smeltzer, S.C., \& Bare, B. G. (2002). Buku Ajar Keperawatan Medical Bedah (Brunner \& Suddarth) (Eds.8) (Vol. 1) (Agung Waluyo, I Made Karyasa, Julia, Y. Kuncara \& Yasmin Asih, Penerjemah). Jakarta: EGC.
Sugiyanto (1998). Perkembangan dan Belajar Motorik. Jakarta: Departemen Pendidikan dan Kebudayaan.

Sukmadinata, Syaodih N. (2012). Metode Penelitian Pendidikan. Bandung: PT Remaja Rosdaka.

Suyono, J. (1995). Deteksi Dini Penyakit Akibat Kerja. Jakarta: Penerbit Buku Kedokteran EGC.

Tambunan, R. D., Danes, V. R., \& Lintong, F. (2016). Perbandingan kapasitas vital paru pada pelajar di dataran tinggi Tomohon dengan pelajar di dataran rendah Manado. eBiomedik, 4(1).

https://ejournal.unsrat.ac.id/index.php/ebi omedik/article/view/12143

Tzani, P., Aiello, M., Colella, M., Verduri, A., Marangio, E., Olivieri, D., \& Chetta, A. (2008). Lung diffusion capacity can predict maximal exercise in apparently healthy heavy smokers. Journal of sports science \& medicine, 7(2), 229. https://www.ncbi.nlm.nih.gov/pmc/article $\underline{\text { s/PMC3761463/ }}$ 